\title{
FAKTOR-FAKTOR YANG MEMPENGARUHI STIGMA MASYARAKAT TERHADAP PENDERITA EPILEPSI DI KOTA PALU
}

\author{
Afifah Idelma Makmur ${ }^{1}$, Wijoyo Halim ${ }^{1 *}$, Masita Muchtar ${ }^{1}$ \\ ${ }^{1}$ Program Studi Pendidikan Dokter, Fakultas Kedokteran Universitas Alkhairat, Jl. Diponegoro No. 39 \\ Palu 94221, Sulawesi Tengah, Indonesia
}

"Corresponding author: Telp: +628124245438 email: wijoyoneuro@gmail.com

\begin{abstract}
ABSTRAK
Epilepsi masih menjadi masalah kesehatan global. Epilepsi tidak dianggap sebagai suatu penyakit oleh beberapa masyarakat namun diduga sesuatu dari luar badan penderita yang biasanya dianggap sebagai kutukan roh jahat atau akibat kekuatan gaib, sehingga memberi dampak negatif pada kualitas hidup penderita bahkan dijauhi dari lingkungan sosial. Anggapan ini masih terdapat di kalangan masyarakat yang belum terjangkau oleh ilmu kedokteran dan pelayanan kesehatan. Penelitian bertujuan untuk mengetahui faktor-faktor yang mempengaruhi stigma masyarakat terhadap penderita epilepsi di Kota Palu. Metode penelitian yang digunakan yaitu Deskriptif Analitik dengan pendekatan cross sectional yang dilaksanakan pada bulan Mei s/d September 2019. Penelitian dilakukan pada 270 responden di 12 kelurahan di Kota Palu dengan teknik pengambilan sampel stratified random sampling. Pengumpulan data dilakukan dengan wawancara dan kuisioner. Hasil penelitian menunjukkan sebanyak $42.6 \%$ responden memiliki tingkat pengetahuan kurang dan sebanyak $57.4 \%$ responden memiliki tingkat pengetahuan cukup. Sebanyak 148 responden (54.8\%) memiliki stigma $\geq 21.00$ dan 122 responden $(45.2 \%)$ memiliki stigma $<21.00$. Sebanyak 159 responden $(58.9 \%)$ mengaku pernah melihat bangkitan epilepsi dan sebanyak 111 responden $(41.1 \%)$ tidak pernah melihat. Sebanyak 93 responden (34.4\%) mengaku memiliki kerabat/rekan Orang Dengan Epilepsi (ODE) dan sebanyak 177 responden $(65.6 \%)$ tidak memiliki. Faktor yang berhubungan dengan terjadinya stigma masyarakat yaitu tingkat pengetahuan $(\mathrm{p}=0.03)(\mathrm{OR}=1.74(95 \% \quad \mathrm{CI}=1.06-2.84))$. Kesimpulan penelitian yaitu faktor yang berhubungan dengan terjadinya stigma masyarakat terhadap penderita epilepsi yaitu tingkat pengetahuan, sedangkan faktor yang tidak memiliki hubungan dengan terjadinya stigma masyarakat terhadap penderita epilepsi yaitu jenis kelamin, usia, agama, suku, status ekonomi, tingkat pendidikan, pengalaman melihat epilepsi dan memiliki kerabat/rekan ODE ( $\mathrm{p}>0.05)$.
\end{abstract}

Kata Kunci: Epilepsi, Kota Palu, Stigma

\section{ABSTRACT}

Epilepsy is still a global health problem. Epilepsy is not considered a disease by some people, but it is suspected that something from outside the sufferer's body is usually considered a curse by an evil spirit or due to supernatural powers, so that it has a negative impact on the quality of life of the sufferer and is even shunned from the social environment. This assumption still exists among people who have not been reached by medical science and health services. This study aims to determine the factors that influence the stigma of society towards people with epilepsy in Palu City. The research method used is descriptive analytical with a cross sectional approach which was carried out from May to September 2019. The study was conducted on 270 respondents in 12 urban villages in Palu City with stratified random sampling technique. Data was collected by means of interviews and questionnaires. The results showed that $42.6 \%$ of respondents had a low level of knowledge and 57.4\% of respondents had a sufficient level of knowledge. A total of 148 respondents (54.8\%) had a stigma of 21.00 and 122 respondents $(45.2 \%)$ had a stigma of $<21.00$. A total of 159 respondents $(58.9 \%)$ claimed to have seen an epileptic seizure and as many as 111 respondents (41.1\%) had never seen it. A total of 93 
respondents (34.4\%) claimed to have relatives/colleagues with people with epilepsy (ODE) and as many as 177 respondents (65.6\%) did not. Factors associated with the occurrence of community stigma is the level of knowledge $(p=0.03)(O R=1.74(95 \% \quad C I=1.06-2.84))$. The conclusion of the study is that the factors related to the occurrence of community stigma against people with epilepsy are the level of knowledge, while factors that do not have a relationship with the occurrence of community stigma against people with epilepsy are gender, age, religion, ethnicity, economic status, education level, experience seeing epilepsy and have ODE relatives/partners $(p>0.05)$.

Keywords: Epilepsy, Palu City, Stigma

\section{PENDAHULUAN}

Epilepsi adalah suatu keadaan yang ditandai oleh bangkitan (seizure) berulang sebagai akibat dari adanya gangguan fungsi otak secara intermitten, yang disebabkan oleh lepas muatan listrik abnormal dan berlebihan di neuron-neuron secara paroksimal, dan disebabkan oleh berbagai etiologi. ${ }^{1}$ Epilepsi tidak dianggap sebagai suatu penyakit, akan tetapi sebabnya diduga sesuatu di luar badan si penderita, biasanya dianggap sebagai kutukan roh jahat atau akibat kekuatan gaib yang menimpa seseorang. Anggapan ini masih terdapat di kalangan masyarakat yang belum terjangkau oleh ilmu kedokteran dan pelayanan kesehatan. $^{2}$

Stigma adalah ciri negatif yang menempel pada pribadi seseorang karena pengaruh lingkungannya (KBBI). Stigma adalah bentuk prasangka (prejudice) yang mendiskreditkan atau menolak seseorang atau kelompok karena mereka dianggap berbeda dengan diri kita atau kebanyakan orang. Stigma berhubungan dengan kekuasaan dan dominasi di masyarakat. Pada puncaknya, stigma akan mencipkan ketidaksetaraan sosial. Stigma berurat akar di dalam struktur masyarakat dan juga dalam norma-norma dan nilai-nilai yang mengatur kehidupan seharihari. Ini menyebabkan beberapa kelompok menjadi kurang dihargai dan merasa malu, sedangkan kelompok lainnya merasa superior. ${ }^{3}$

Epilepsi adalah penyakit kronis tidak menular pada otak yang mempengaruhi sekitar 50 juta orang di seluruh dunia. ${ }^{4}$ Pada data Dinas Kesehatan Kota Palu pada tahun 2014 tercatat 87 kasus baru dan 208 kasus lama, tahun 2015 tercatat 104 kasus baru dan 213 kasus lama, tahun 2016 tercatat 91 kasus baru dan 229 kasus lama, dan tahun 2017 tercatat
117 kasus baru dan 293 kasus lama. Sedangkan data yang didapatkan dari Poliklinik Neurologi RSU Anutapura Palu pada tahun 2015 tercatat sebanyak 146 kasus baru, pada tahun 2016 tercatat 285 kasus baru, pada tahun 2017 tercatat 109 kasus baru, pada tahun 2018 tercatat 141 kasus baru, dan pada tahun 2019 dipriode triwulan I sampai triwulan III sebanyak 88 kasus baru.

Akibat dari stigma epilepsi mengikis status sosial dan jaringan sosial seseorang, yang semuanya berkontribusi pada hasil buruk seperti isolasi karena kurang percaya diri dan tersudutkan, pengangguran, prospek pernikahan yang lebih rendah,malu, cemas, depresi dan tidak mencari pengobatan. ${ }^{5,6,7}$

Tujuan dari penelitian ini yaitu untuk mengetahui bagaimana hubungan faktor-faktor yang mempengaruhi stigma masyarakat terhadap penderita epilepsi di Kota Palu pada tahun 2019.

\section{METODOLOGI}

Metode penelitian yang digunakan adalah Deskriptif Analitik dengan pendekatan cross sectional. Subyek Penelitian adalah masyarakat yang berada di Kota Palu dan memenuhi syarat penelitian yang dilakukan secara stratified random sampling pada bulan Mei sampai dengan September 2019. Untuk menghitung besar sampel yang akan digunakan dalam penelitian ini, maka digunakan tabel yang dikembangkan oleh Isaac and Michael. Besar sampel pada penelitian ini adalah sebagai berikut:

$$
\mathrm{s}=\frac{\lambda^{2} \cdot \mathrm{N} \cdot \mathrm{P} \cdot \mathrm{Q}}{\mathrm{d}^{2}(\mathrm{~N}-1)+\lambda^{2} \cdot \mathrm{N} \cdot \mathrm{P} \cdot \mathrm{Q}}
$$


Diketahui besar populasi penduduk Kota Palu berjumlah 369.614 orang. Berdasarkan dari tabel yang dikembangkan Isaac dan Michael dengan tingkat kesalahan 10\%, maka didapatkan besar sampel yang dibutuhkan adalah 270 orang pada 12 kelurahan yang jumlahnya ditentukan dari jumlah orang di kelurahan dibagi jumlah dari 12 kelurahan lalu dikalikan dengan jumlah sampel yaitu di Kelurahan Kamonji (23 responden), Kelurahan Lere (30 responden), Kelurahan Siranindi (16 responden), Kelurahan Birobuli Utara (53 responden), Kelurahan Tatura Selatan (31 responden), Kelurahan Buluri (10 responden), Kelurahan Donggala Kodi (27 responden), Kelurahan Watusampu (7 responden), Kelurahan Tipo (11 responden), Kelurahan Nunu (11 responden), Kelurahan Tavanjuka (14 responden) dan Kelurahan Bayaoge (24 responden).

Analisa yang digunakan untuk mengetahui faktor-faktor yang mempengaruhi stigma masyarakat terhadap epilepsi yaitu analisa bivariat. Analisa bivariat akan digunakan untuk mencari korelasi dua variable tersebut. Data penelitian ini akan diolah menggunakan perangkat lunak komputer program SPSS 25.

\section{HASIL DAN PEMBAHASAN}

HASIL

\section{Gambaran tingkat pengetahuan masyarakat terhadap epilepsi di Kota Palu.}

Tabel 1. Gambaran tingkat pengetahuan masyarakat terhadap epilepsi di Kota Palu.

\begin{tabular}{ccc}
\hline $\begin{array}{c}\text { Variabel } \\
\text { (tingkat pengetahuan) }\end{array}$ & $\mathrm{N}$ & Presentase \% \\
\hline $\begin{array}{c}\text { Dikatakan kurang bila } \\
\text { skor } \leq 50 \%\end{array}$ & 115 & 42.6 \\
$\begin{array}{c}\text { Diakatakan cukup bila } \\
\text { skor }>50 \%\end{array}$ & 155 & 57.4 \\
\hline Total & 270 & 100.0 \\
\hline
\end{tabular}

Tabel 1 menujukkan bahwa sebanyak 115 responden $(42.6 \%)$ memiliki tingkat pengetahuan kurang dan sebanyak 155 responden $(57.4 \%)$ memiliki tingkat pengetahuan cukup.
2. Gambaran stigma masyarakat terhadap epilepsi.

Tabel 2. Gambaran masyarakat yang pernah melihat bangkitan epilepsi.

$$
\text { Variabel }
$$

(pernah melihat bangkitan $\mathrm{N}$ Persentase \% epilepsi)

\begin{tabular}{ccc} 
Ya & 159 & 58.9 \\
Tidak & 111 & 41.1 \\
\hline Total & 37 & 100.0
\end{tabular}

Tabel 2 menunjukkan bahwa sebanyak 159 responden $(58.9 \%)$ mengaku pernah melihat bangkitan epilepsi dan sebanyak 111 responden $(41.1 \%)$ tidak pernah melihat bangkitan epilepsi.

3. Gambaran masyarakat yang memiliki kerabat/rekan orang dengan epilepsi.

Tabel 3. Gambaran masyarakat yang memiliki kerabat/rekan orang dengan epilepsi.

\begin{tabular}{ccc}
\hline $\begin{array}{c}\text { Variabel } \\
\text { (memiliki kerabat ODE) }\end{array}$ & $\mathrm{N}$ & $\begin{array}{c}\text { Peresentase } \\
\%\end{array}$ \\
\hline Ya & 93 & 34.4 \\
Tidak & 117 & 65.6 \\
\hline Total & 37 & 100.0 \\
\hline
\end{tabular}

Tabel 3 menunjukkan bahwa sebanyak 93 responden (34.4\%) mengaku memiliki kerabat/rekan ODE dan sebanyak 177 responden $(65.6 \%)$ tidak memiliki kerabat/rekan ODE.

\section{Faktor-faktor yang mempengaruhi} terjadinya stigma masyarakat terhadap penderita epilepsi.

Tabel 4 menunjukkan pada uji Chi-square memperlihatkan adanya hubungan bermakna antara tingkat pengetahuan dan stigma dengan nilai p-value 0.03 . Dari 115 orang yang memiliki pengetahuan kurang,sebanyak 72 $(62,6 \%)$ yang memberikan stigma $\geq 21.00$, sedangkan dari 155 orang yang memiliki pengetahuan cukup terdapat $76(49 \%)$ yang memberikan stigma $\geq 21.00$ dengan $\mathrm{OR}=1.74$ (95\% CI=1.06-2.84), yang artinya orang yang berpengetahuan kurang memiliki kemungkinan 1.74 kali untuk terbentuknya stigma terhadap orang dengan epilepsi. 
Tabel 4. Analisis Bivariat (Chi-Square)

\begin{tabular}{|c|c|c|c|c|c|}
\hline & $\begin{array}{l}\text { Stigma } \\
\geq 21.00 \\
\mathrm{n}=148\end{array}$ & $\begin{array}{l}\text { Stigma } \\
<21.00 \\
\mathrm{n}=122\end{array}$ & OR & $95 \% \mathrm{CI}$ & $\mathrm{p}$ value \\
\hline $\begin{array}{l}\text { Laki-laki } \\
\text { Perempuan }\end{array}$ & $\begin{array}{l}73(58.4 \%) \\
75(51.7 \%)\end{array}$ & $\begin{array}{l}52(41.6 \%) \\
70(48.3 \%)\end{array}$ & 1.31 & $0.80-2.12$ & 0.32 \\
\hline $\begin{array}{r}\text { Remaja } \\
(\leq 25 \text { tahun }) \\
\text { Dewasa } \\
(>25 \text { tahun })\end{array}$ & $\begin{array}{l}54(49.5 \%) \\
94(58.4 \%)\end{array}$ & $\begin{array}{l}55(50.5 \%) \\
67(41.6)\end{array}$ & 0.70 & $0.42-1.14$ & 0.19 \\
\hline $\begin{array}{r}\text { Kaili } \\
\text { Lainnya }\end{array}$ & $\begin{array}{l}50(55.6 \%) \\
98(54.8 \%)\end{array}$ & $\begin{array}{l}40(44.4 \%) \\
82(45.6 \%)\end{array}$ & 1.04 & $0.62-1.74$ & 0.96 \\
\hline Tingkat Pendidikan & $\begin{array}{l}108(54 \%) \\
40(57.1 \%)\end{array}$ & $\begin{array}{c}92(46 \%) \\
30(42.9 \%)\end{array}$ & 0.88 & $0.50-1.52$ & 0.75 \\
\hline $\begin{array}{r}\text { Tingkat Pengetahuan } \\
\text { Kurang } \\
\text { Cukup }\end{array}$ & $\begin{array}{l}72(62.6 \%) \\
76(49 \%)\end{array}$ & $\begin{array}{c}43(37.4 \%) \\
79(51 \%)\end{array}$ & 1.74 & $1.06-2.84$ & 0.03 \\
\hline $\begin{array}{l}\text { Pengalaman melihat } \\
\text { bangkitan }\end{array}$ & $\begin{array}{l}82(51.6 \%) \\
66(59.5 \%)\end{array}$ & $\begin{array}{l}77(48.4 \%) \\
45(40.5 \%)\end{array}$ & 0.72 & $0.44-1.18$ & 0.24 \\
\hline $\begin{array}{r}\text { Memiliki kerabat/rekan ODE } \\
\text { Ya } \\
\text { Tidak }\end{array}$ & $\begin{array}{l}54(58.1 \%) \\
94(53.1 \%)\end{array}$ & $\begin{array}{l}39(41.9 \%) \\
83(46.9 \%)\end{array}$ & 1.22 & $0.73-2.02$ & 0.51 \\
\hline
\end{tabular}

Tabel 4 memperlihatkan tidak terdapat hubungan bermakna antara jenis kelamin dengan terjadinya stigma masyarakat terhadap penderita epilepsi dengan nilai p-value 0.32 . Responden berjenis kelamin laki-laki lebih dominan memiliki stigma $\geq 21.00$ dengan persentase $58.4 \%$, sedangkan responden berjenis kelamin perempuan sebanyak $51.7 \%$ memiliki stigma $\geq 21.00$.

Tidak terdapat hubungan bermakna antara usia dengan terjadinya stigma masyarakat terhadap penderita epilepsi dengan nilai $p$ value 0.19 , dimana responden berusia remaja ( $<25$ tahun) lebih banyak memberikan stigma $<21.00$ dengan persentasi $50.5 \%$ sedangkan pada usia dewasa ( $>25$ tahun) sebanyak $58.4 \%$ memiliki stigma $\geq 21.00$.

Tidak terdapat hubungan bermakna antara suku dengan terjadinya stigma masyarakat terhadap penderita epilepsi dengan nilai $p$ value 0.96 .Tidak terdapat hubungan bermakna antara status ekonomi dengan terjadinya stigma masyarakat terhadap penderita epilepsi dengan nilai pvalue 0.93.Tidak terdapat hubungan bermakna antara tingkat pendidikan dengan terjadinya stigma masyarakat terhadap penderita epilepsi dengan nilai p-value 0.63. Tidak terdapat hubungan bermakna antara pengalama melihat bangkitan epilepsi dengan terjadinya stigma masyarakat terhadap penderita epilepsi dengan nilai $\mathrm{p}$ value 0.24 , dan dari Tabel 4 juga menunjukkan bahwa tidak ada hubungan bermakna antara memiliki kerabat/rekan ODE dengan terjadinya stigma masyrakat terhadap penderita epilepsi dengan nilai p-value 0.51 . 


\section{PEMBAHASAN}

1. Gambaran tingkat pengetahuan masyarakat terhadap epilepsi di Kota Palu.

Berdasarkan hasil penelitian yang telah dilakukan pada masyarakat di Kota Palu tahun 2019 diketahui bahwa 155 responden $(57.4 \%)$ memiliki tingkat pengetahuan cukup dan sebanyak 115 responden $(42.6 \%)$ memiliki tingkat pengetahuan kurang. Hal ini sejalan dengan penelitian yang di lakukan olah Gunawan D pada tahun 2014 di Kabupaten Mahena sebanyak 57\% responden memiliki pengetahuan cukup terhadap epilepsi dan sebanyak $43 \%$ responden memiliki pengetahuan kurang terhadap epilepsi. ${ }^{8}$

Dilihat dari dua penelitian ini memang terdapat lebih banyak responden yang memiliki pengetahuan baik, tapi tidak terpaut jauh dari jumlah responden yang memiliki pengetahuan yang kurang sehingga masih banyak masyarakat memiliki pengetahuan yang kurang walaupun lebih banyak yang memiliki pengetahuan yang baik.

Menurut Lawrence W.Green Dalam buku Soekidjo Notoatmodjo yang dituliskan pada tahun 2012 mengatakan bahwa salah satu faktor penentu terjadinya perubahan perilaku adalah adanya faktor permudah (predisposing factor) yang di dalamnya termasuk tingkat pengetahuan. Di dalam buku tersebut dituliskan pengetahuan merupakan domain yang sangat penting untuk terbentuknya tindakan seseorang. Pengetahuan seseorang pada umumnya didapatkan melalui pendidikan formal, tetapi bisa juga didapatkan diluar pendidikan formal (informal) bisa dari kegiatan penyuluhan kesehatan atau informasi dari orang ke orang. ${ }^{5}$

\section{Gambaran stigma masyarakat terhadap epilepsi.}

Berdasarkan hasil penelitian yang telah dilakukan pada masyarakat di Kota Palu tahun 2019 didapatkan yaitu $54.8 \%$ responden memberikan stigma dengan skor $\geq 21.00$ dan sebanyak $45.2 \%$ responden memberikan stigma dengan skor $<21.00$. Hal ini sejalan dengan penelitian yang dilakukan oleh Yushtin dkk pada tahun 2018 di Kota Semarang yang melakukan penelitian tentang faktor eksternal dan internal yang mempengaruhi stigma terhadap orang dengan epilepsi,dimana hasil yang ditemukan $54.2 \%$ responden memberikan stigma dengan skor $\geq 20.73$ dan sebanyak $45.8 \%$ responden yang memberikan stigma dengan skor $<20.73{ }^{6}$

\section{Hubungan antara jenis kelamin dengan} terjadinya stigma masyarakat terhadap penderita epilepsi di Kota Palu.

Berdasarkan hasil penelitian yang dilakukan, tidak ditemukan hubungan yang bermakna antara jenis kelamin dengan terjadinya stigma terhadap penderita epilepsi di Kota Palu dengan nilai p-value 0.32. Dari 125 orang berjenis kelamin laki-laki memiliki stigma $\geq 21.00$ dengan persentase $58.4 \%$ (73 orang) sedangkan responden perempuan yang terdiri dari 145 orang memiliki stigma $\geq 21.00$ dengan persentase $51.7 \%$ (75 orang). Penelitian ini sejalan dengan penelitian yang dilakukan oleh Yusthin dkk pada tahun 2018, menemukan bahwa tidak ada hubungan antara jenis kelamin dengan terjadinya stigma dengan nilai p-value 0.47 dimana laki-laki $56.6 \%$ dan perempuan $52 \%$ memberikan stigma $\geq 20.73{ }^{6}$

\section{Hubungan antara usia dengan terjadinya stigma masyarakat terhadap penderita epilepsi di Kota Palu}

Berdasarkan hasil penelitian yang dilakukan, tidak ditemukan hubungan yang bermakna antara usia dengan terjadinya stigma terhadap penderita epilepsi di Kota Palu dengan nilai $\mathrm{p}$-value 0.19 , dimana responden berusia remaja ( $<25$ tahun) lebih banyak memberikan stigma skor $<21.00$ dengan persentasi $50.5 \%$ sedangkan pada usia dewasa (>25 tahun) sebanyak 58.4\% memiliki stigma $\geq 21.00$. Penelitian ini sejalan dengan penelitian yang dilakukan oleh Yusthin dkk pada tahun 2018, menemukan bahwa tidak ada hubungan antara usia dengan terjadinya stigma dengan nilai $\mathrm{p}$-value 0.19 , dimana usia remaja dan dewasa dominan memberikan stigma $\geq 20.73$ dengan persentasi usia remaja $52.3 \%$ dan usia dewasa $55.8 \% .^{6}$ 


\section{Hubungan antara suku dengan terjadinya} stigma masyarakat terhadap penderita epilepsi di Kota Palu

Berdasarkan hasil penelitian yang dilakukan, tidak ditemukan hubungan yang bermakna antara suku dengan terjadinya stigma terhadap penderita epilepsi di Kota Palu dengan nilai $\mathrm{p}$ value 0.96 . Dari 90 orang yang bersuku Kaili terdapat 50 (55.6\%) yang memberikan stigma $\geq 21.00$, sedangkan suku lainnya terdiri dari 280 orang terdapat 98 $(54.8 \%)$ yang memiliki stigma $\geq 21.00$. Menurut Lawrence W.Green dalam buku Soekidjo Notoatmodjo yang dituliskan pada tahun 2012 mengatakan bahwa salah satu faktor penentu terjadinya perubahan perilaku adalah adanya faktor permudah (predisposing factor) yang di dalamnya termasuk kepercayaan dan keyakinan. Dalam setiap suku ada budaya yang di wariskan secara turun temurun, begitupun terhadap pemberian stigma terhadap penderita epilepsi. Daerah NTT sudah menjadi budaya yang tidak dapat hilang dari pemikiran masyarakat yaitupenyakit epilepsi terjadi karena adanya kutukan, sedangkan di India penganut animisme Hmong di sebuah negara Afrika bernama Tanzania, menganggap epilepsi sebagai serangan dari roh jahat. Penderita epilepsi yang terkena serangan dari roh jahat ini diyakini bisa memiliki kekuatan magis. ${ }^{9}$

Di beberapa budaya, epilepsi malah tidak diartikan dengan pengalaman spiri-tual, melainkan identik dengan kegilaan. Para penderita ini dijauhi, dikucilkan, bahkan sampai dipenjarakan. ${ }^{9}$

6. Hubungan antara status ekonomi dengan terjadinya stigma masyarakat terhadap penderita epilepsi di Kota Palu

Berdasarkan hasil penelitian yang dilakukan, tidak di temukan hubungan yang bermakna antara status ekonomi dengan terjadinya stigma terhadap penderita epilepsi di Kota Palu dengan nilai p-value 0.93. Dari 159 orang yang memiliki status ekonomi rendah sebanyak $88(55.3 \%)$ yang memberikan stigma $\geq 21.00$, sedangkan dari 111 orang yang memiliki status ekonomi tinggi terdapat $60(54.1 \%)$ yang memberikan stigma $\geq 21.00$.
Status ekonomi pada dasarnya memiliki pengaruh terhadap pemberian stigma seseorang. Karena rendahnya ekonomi seseorang akan mempengaruhi seseorang dalam memperoleh pendidikan dan pengetahuan serta informasi mengenai epilepsi. Yang cukup menarik di India, sebagian besar stigma sosial yang terkait dengan gangguan epilepsi terletak pada orang kaya di perkotaan, dan bukan kaum miskin di pedesaan. Orang miskin pedesaan tidak menganggap epilepsi masalah besar karena keluarga merawat mereka yang sakit, pasien dengan epilepsi tidak ditinggalkan oleh keluarga, dan mereka diizinkan untuk menikah dan diterima dalam masyarakat. ${ }^{9}$

\section{Hubungan antara tingkat pendidikan} dengan terjadinya stigma masyarakat terhadap penderita epilepsi di Kota Palu

Berdasarkan hasil penelitian yang dilakukan, tidak ditemukan hubungan yang bermakna antara tingkat pendidikan dengan terjadinya stigma terhadap penderita epilepsi di Kota Palu dengan nilai p-value 0.63, dari 200 orang yang berpendidikan dasar terdapat $108(53.7 \%)$ yang memiliki stigma $\geq 21.00$, sedangkan tingkat pendidikan tinggi dari 70 orang terdapat 40 orang yang memberiikan stigma $\geq 21.00$. Penelitian ini sejalan dengan penelitian yang dilakukan oleh Yusthin dkk pada tahun 2018, menemukan bahwa tidak ada hubungan antara tingkat pendidikan dengan terjadinya stigma dengan nilai p-value 0.07 , dimana tingkat pendidikan dasar terdapat $55 \%$ orang yang memberikan memberikan stigma $\geq 20.73$, sedangkan pada pendidikan tinggi terdapat $54,2 \%$ orang yang memberikan stigma $\geq 20.73{ }^{6}$

\section{Hubungan antara tingkat pengetahuan} dengan terjadinya stigma masyarakat terhadap penderita epilepsi di Kota Palu

Berdasarkan hasil penelitian yang dilakukan, ditemukan hubungan yang bermakna antara tingkat pengetahuan dengan terjadinya stigma terhadap penderita epilepsi di Kota Palu dengan nilai p-value 0.03. Dari 115 orang yang memiliki pengetahuan kurang, sebanyak $72(62,6 \%)$ yang memberikan stigma 
$\geq 21.00$, sedangkan dari 155 orangyang memiliki pengetahuan cukup terdapat 76 $(49 \%)$ yang memberikan stigma $\geq 21.00$ dengan $\mathrm{OR}=1.74(95 \% \mathrm{CI}=1.06-2.84)$, yang artinya orang yang berpengetahuan kurang memiliki kemungkinan 1.74 kali untuk terbentuknya stigma terhadap orang dengan epilepsi. Hal ini sesuai dengan penelitian Yusthin pada tahun 2018 yang mengatakan bahwa stigma terhadap penderita epilepsi lebih banyak diberikan oleh responden yang berpengatahuan kurang. ${ }^{6}$

9. Hubungan antara pengalaman melihat bangkitan dengan terjadinya stigma masyarakat terhadap penderita epilepsi di Kota Palu

Berdasarkan hasil penelitian yang dilakukan, tidak ditemukan hubungan yang bermakna antara pengalaman melihat bangkitan epilepsi dengan terjadinya stigma terhadap penderita epilepsi di Kota Palu dengan nilai p-value 0.24. Dari 159 yang pernah melihat bangkitan epilepsi terdapat 82 $(51.6 \%)$ yang memberikan stigma $\geq 21.00$, sedangkan yang tidak pernah melihat bangkitan epilepsi sebanyak 111 orang terdapat $66(59.5 \%)$ yang memberikan stigma $\geq 21.00$. Berbeda dengan hasil penelitian yang dilakukan oleh Yusthin dkk pada tahun 2018, dimana dia menemukan bahwa adanya hubungan antara pengalaman melihat bangkitan epilepsi dengan proses terjadinya stigma dengan nilai p-value $0.03 .^{6}$

Informasi yang dimiliki seseorang akan mempengaruhi sikap dan persepsi/keyakinan seseorang terhadap apa yang dilihatnya, memberikan reaksi yang salah/negatif terhadap serangan epilepsi, sehingga penting untuk memberikan pengetahuan baik secara visual maupun verbal.

10. Hubungan antara memiliki kerabat/rekan ODE dengan terjadinya stigma masyarakat terhadap penderita epilepsi di Kota Palu

Berdasarkan hasil penelitian yang dilakukan, tidak ditemukan hubungan yang bermakna antara memiliki kerabat/rekan ODE dengan terjadinya stigma terhadap penderita epilepsi di Kota Palu dengan nilai p-value 0.51 , dimana terdapat $58.1 \%$ responden yang memiliki kerabat/rekan ODE memberikan stigma $\geq 21.00$, sedangkan responden yang tidak memiliki kerabat/rekan ODE terdapat $53.1 \%$ yang memberikan stigma $\geq 21.00$. Berbeda dengan hasil penelitian yang dilakukan oleh Yusthin dkk pada tahun 2018, dimana dia menemukan bahwa adanya hubungan antara memiliki kerabat/rekan ODE dengan terjadinya stigma dengan nilai $\mathrm{p}$-value 0.02 .

Penelitian Karimi (2016) menunjukkan bahwa kepemilikan kerabat atau rekan dengan epilepsi cenderung memiliki pengetahuan yang baik dan juga sikap yang baik tentang epilepsi atau lebih familiar dengan epilepsi, yang akhirnya berpengaruh terhadap tindakan yang positif terhadap orang dengan epilepsi. ${ }^{10}$

\section{KESIMPULAN}

Berdasarkan hasil penelitian tentang faktor-faktor yang mempengaruhi stigma masyarakat terhadap penderita epilepsi di Kota Palu, dapat disimpulkan sebagai berikut:

1. Tingkat stigma masyarakat terhadap penderita epilepsi di Kota Palu yaitu sebanyak 148 responden (54.8\%) memiliki stigma $\geq 21.00$ dan sebanyak 122 responden $(45.2 \%)$ memiliki stigma < 21.00.

2. Faktor yang mempunyai hubungan yang bermakna yaitu tingkat pengetahuan dengan terjadinya stigma masyarakat terhadap penderita epilepsi di Kota Palu $(\mathrm{p}=0.03)$ dimana terjadinya stigma yang tinggi berhubungan dengan pengetahuan yang kurang. Sedangkan faktor yang tidak memiliki hubungan dengan terjadinya stigma masyarakat terhadap penderita epilepsi yaitu jenis kelamin, usia, agama, suku, status ekonomi, tingkat pendidikan, pengalaman melihat epilepsi dan memiliki kerabat/rekan ODE ( $p>0.05)$. 


\section{DAFTAR PUSTAKA}

1. Munir, B. Neorologi dasar edisi kedua. Yogyakarta: Sagung Seto.2017.

2. Harsono. Buku ajar neorologi klinis. Yogyakarta: Gajah Mada University Press.2015.

3. Ardhiyanti, Yulrina. AIDS pada Asuhan Kebidanan. Yogykarta. CV. Budi Utama.2015.

4. World Health Organization. Epilepsy. [Online]. 2017 Feb [cited 2017 May 31]; [5 screens]. Available from: URL:http://www.who.int/mediacentre/fact sheets/fs999/en/

5. Notoatmodjo, Soekidjo. 2012. Metodologi Penelitian Kesehatan. Jakarta: Rineka Cipta.

6. Manglapy YM, Fani T. Faktor Eksternal dan Internal yang Mempengaruhi Stigma terhadap Orang dengan Epilepsi di Kalangan Akademisi. Jurnal Promosi Kesehatan Indonesia Vol. 13 / No. 2 / Agustus 2018 Available from URL: https://ejournal.undip.ac.id/index.php/jpki/ article/downloadSuppFile/20197/2709

7. Nevin, Nihan, Aydin S. Validation and Reliability Study of the Turkish Version of the Stigma Scale of Epilepsy. Arch Neuropsychiatry. 2017.

8. Gunawan D, Gambaran tingkat pengetahuan masyarakat tentang epilepsi di kelurahan mahena kecamatan tahuna kabupaten sangihe. 2014. Available from : URL:https://www.google.com/urlGambara n_tingkat_pengetahuan_masyarakat_tentan g_epilepsi_di_kelurahan_mahena_kecamat an_tahuna_kabupaten_sangihe

9. Maryanti NCW. Epilepsi dan budaya buletin psikologi. 2016 Available from: URL:https://jurnal.ugm.ac.id/buletinpsikol ogi/article/download/16358/pdf

10. Karimi N, Akbarian SA. Knowledgeand Attitude toward Epilepsy of Close Family Members of People with Epilepsy in North of Iran. Adv Med. 2016. 